\title{
The Progress on Cultivation and Identification of the First Wuzhishan Inbred Mini-Pig in China
}

\author{
Shutang Feng ${ }^{1,2 *}$, Xiuling Zhang ${ }^{1}$ and Taiping Wang ${ }^{2}$ \\ ${ }^{1}$ Department of Gene and Cell Engineering, Institute of Animal science, China \\ ${ }^{2}$ Grand life science and Technology L ta, China
}

Submission: November 23, 2017; Published: December 11, 2017

"Corresponding author: Shutang Feng, Department of Gene and Cell Engineering, Institute of Animal science, Chinese Academy of Agricultural Sciences, China, Email: fst508@sina.com

\begin{abstract}
Research results of mini-pig inbred cultivation and identification, which were achieved by the scientists from Institute of Animal Sciences of Chinese Academy of Agricultural Sciences (CAAS). By comprehensive measures of "inbreeding" of improving the level of nutrition, estrus synchronization and cage rearing technology et al. which lasted 28 years. We bred international's first inbred pigs with two Wuzhishan minipig (WZSP) (Sus scrofa) as progenitor and gradually overcame three stages problems as high offspring malformation rate, high weakling piglet rate and low survival rate. This article describes the breeding process, inbred line identification, germplasm characteristics of the new genetic resources and their development and utilization et al. The results fill the gaps for pig inbred line in domestic and foreign research, and provide a new vision for animal inbreeding theory and applied research in large mammals inbred line.
\end{abstract}

Keywords: Wuzhishan miniature pig; Inbreed line; Genome

\section{Background and Significance}

A lot of research results have told us that: Data obtained from rodents as medical models faces significant limitations in that the gap between rodents and human being is too large. And miniature pig bears a similarity with human in morphology, anatomy, physiology, diet, nutrition, metabolism and genome sequence so that serves as ideal large animal model. Since the end of the second world war, more than 20 miniature pig strains have been developed and great amount research and application rely on those special types of swine to help to solve human difficult diseases for the benefit human. Yet true inbred line of miniature pig has yet been bred. For example, the miniature pig bred of Yucatan mini-pig, Sinclair mini-pig, Hanford mini-pig, Minnesota mini-pig, Pitman-Moore mini-pig, Hairless mini-pig in USA, the miniature pig bred of Gottingen mini-pig, Corsica minipig, Potbelly min-pig, Clown mini-pig, Oh mini-pig in Europe and Asia $[1,2]$.

There are more tha No.7 mini-pig bred in China also, such as Xiang pig, Bema pig, Wuzhishan pig (WZSP), Logline pig, Tibetan pig, Diqing, Taiwan song li pig et al., Domestic miniature pig breeds with a small size and genetic stability [2]. WZSP is one of the scarce breed originated from the mountain area of Hainan province, which is becoming extinct in China since 1987, duo to with a characterized by its small body size and the weight of sow is about $35-40 \mathrm{~kg}$ at 24 month of age [1]. In order to save the valuable resources and in the development and utilization of experimental animals, it is began to the long distance race and inbred line breeding with one male and one female only in Beijing since 1998 [1].

Since ex-situ breeding successful of WZSP and inbred strain of WZSP has made a progress by scientists of CAAS for over 28 years, a series studies have been carried out on germplam evaluation, laboratory rearing and The establishment of minipig inbred line [03] idenfication of Wuzhishan miniature inbred line and Outstanding germplasm characteristics and widely application et al. But it did not see the report of inbred successfully by the skin allograft appraisal also [3-7].

\section{The Establishment of Mini-Pig Inbred Line}

As we know that there is no inbred line successfully in the world. So the inbred line of cultivation must be completed the process to set up the F20 and to establish an identification method of inbred line and to establish a standard strains and the difference between inbred line and Hainan wuzhishan pig especially.

\section{The process of WZSP Inbred line breeding [02]}

It was achieved by comprehensive measures (ZL 02149030.9) of "inbreeding ", improving the level of nutrition, estrus synch and cage rearing technology et al., which lasted 25 
years since 1989. We have bred the first inbred pig with 2 WZSP as progenitor, gradually overcome three stages problems as high rate of deformity and high rate of weakling piglets and low survival rate. The survival rate of piglets is gradually increase from $19.05 \%$ to $90 \%$ individually. The piglets of F20 was born under till in 2009. Currently, >500 population of F20 - F25 has been cultivated with the inbreeding coefficient as high as 0.995 after 28 years [4,5] (Figure 1).

From the Figure $1 \& 2$, you can clear to see that the characteristics of inbred line with a white star on heard, mouth slightly longer, small ears upright et al; sexual maturity at 4-6 months , nest litter $6-8$ head, birth weight $0.33 \pm 0.083 \mathrm{Kg}, 1$ months $2.94 \pm 0.55 \mathrm{Kg}, 5.55 \pm 1.30 \mathrm{Kg}$ at 2 months, $15 \mathrm{Kg}$ at 6 months, $23 \mathrm{Kg}$ at 12 months , $35 \mathrm{Kg}$ weight $\pm 3.27 \mathrm{Kg}$ at 24 months. According to the fitting formula: $\mathrm{W}=4594.15 \mathrm{e} 0.0063 \mathrm{t}$ can estimate body weight $(\mathrm{t}=0.7782)$. Adult body $45 \mathrm{~cm}$, length $72 \mathrm{~cm}$ high, inbred line pig with a small, early sexual maturity, genetic stability [2] etc. The pedigree of inbred line has been set up at 1989-2017 already (Figure 2).

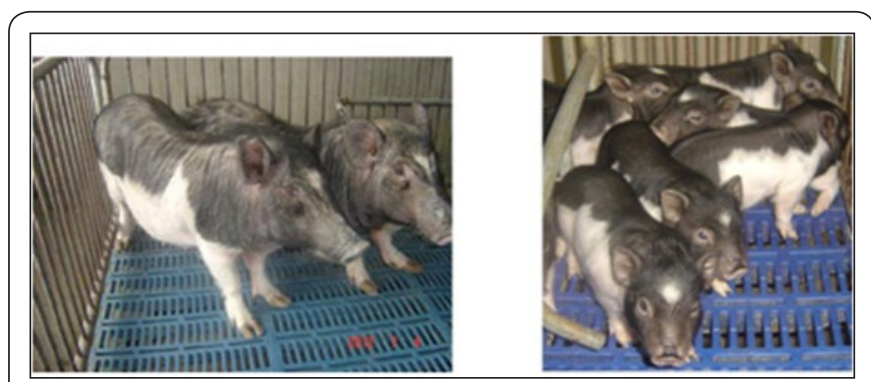

Figure 1: Adult inbreed pig and piglets on day30.

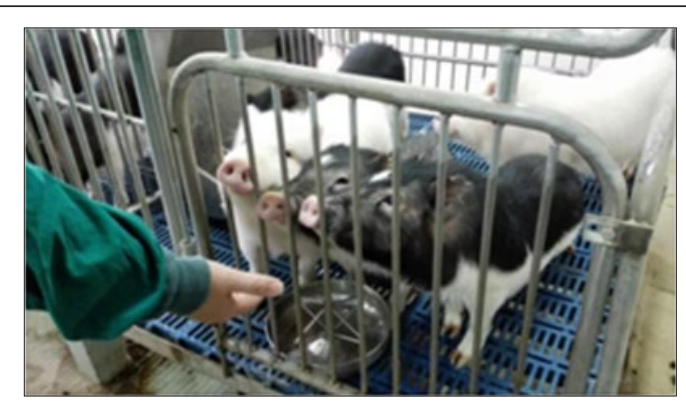

Figure 2 : Adult inbreed pig and piglets on day30.

\section{Idenfication of Wuzhishan Miniature Inbred Line}

\section{Allograft identification of pig inbred line [3]}

As we know that: Skin transplantation is the traditional identification method of inbred line. The Army General Hospital has been proved allograft and auto grafts no immune rejection by morphology observation and no immune rejection by Immuno histochemical analysis of $\mathrm{HE}$ and Masson and no immune rejection by Allografts and autologous no immune rejection by elegant indicators tendency (IL-2,IL-4,IL-10,CD4+,CD8+) in the peripheral blood also. It has been proved a theoretical basis no immune rejection by the homozygous MHC genes of Chr.7 in 48 head WZSP at F20 to-F22 [3].
No immune rejection by homozygous of the whole genome sequence collaborated with BGI. It has proved that the homozygous of whole genome sequence is a high as $60 \%$, it similar to inbred line mouse, non inbred line animal can be only $8-11 \%$ [8].

It has proved that the inbred's with PERV-A,B less copy, without PERV-C copy; There are 247 cardiovascular disease genes only missing ARMS2 and CETP which is compared to Human non inbred pig; Homologous rate With the human 1624 drug target gene is as high as $99.6 \%$. At the gene level proves that the inbred line is the ideal of human disease animal model $[3,8]$.

Identification by protein detection and analysis of SNP loci and microsatellite markers, specific Allele et al. [2,6,9]. Which has proved sever patents methods. Finally, we have put forward the five appraisal criteria of inbred pig line [10].

\section{Inbred is New Genetic Resource [2,6,9]}

Using pig high-density SNP chips, to f-17 thunder 96 samples to making a total of six generations of genotype analysis system, with 16 Hainan wuzhishan pig group as a control. The result show that the inbred is new genetic resource (It will be published in).

\section{Application}

It has provided SPF level and clean experiment animal with thousands of inbred pig to Beijing and Tianjin and the surrounding provinces more than 70 units. It has successfully applied in Beijing experimental pigs standards, models of human diseases, drug preclinical evaluation, genetically modified food safety, xeno transplantation and medicinal materials production in various fields, such as Swine model for atherosclerosis and corneal cells transplantation from swine to monkey and liver of GTO transgenic pigs liver transplant to monkey successfully and so on.

\section{Acknowledgment}

This work was supported by Agricultural Science and Technology Innovation Program (ASTIP -IAS02, ASTIP -IAS03, ASTIP -IAS16) National High Technology Research and Development program of China (2012AA020603) and National Transgenic Major Project (2008ZX08012-002-05).

\section{References}

1. Feng (1999) Chinese Wuzhishan miniature pig. China Agricultural Science Press, Beijing, China.

2. Feng (2011) Chinese Experimental Miniature Pig. China Agriculture Press, Beijing, China.

3. Mu YL, Liu L, Feng ST, Wu TW, Li JY, et al. (2015) Identification of the first miniature pig inbred line by skin graft. Journal of Integrative Agriculture 14(7): 1376-1382.

4. Dnquesnoy (2000) Editor-in-chief, Li YP Transplantation immuno biology. Science Press, Beijing, China, pp. 617-618.

5. Mezrich JD, Haller GW, Arn JS, Houser SL, Madsen JC, et al. (2003) Histocompatible miniature swine: an inbred large-animal model. Transplantation 75(6): 904-907. 
6. Feng Li, Liu L, Gao Q, Cheng Y, Mu YL (2015) Cultivation and application of new variety of miniature Pig (Sus scrofa) inbred line. Journal of Agricultural Biotechnology 23(2): 274-280.

7. Zhu XH, Su BY, Ying DJ (2004) Anatomy histology of Banna minipig inbred line. Higher Education Press, Beijing, China.

8. Fang XD, Mu YL, Huang ZY, Li Y, Han LJ, et al. (2014) The sequence and analysis of an inbred pig genome. Giga Science 1(1): 16.
9. Feng ST, Li K, Mu YL, Yang SL (2012) Inbreeding line culture of Wuzhishan mini-pig and the innovation in nurturing inbred for Chinese genetic resources. Journal of Agricultural Biotechnology 20(8): 849857.

10. Mu YL, Li K, Feng ST (2015) Cultivar identification standard of miniature pig inbred line (draft). Laboratory Animal Science 12(2): 34.

\begin{tabular}{l} 
Your next submission with Juniper Publishers \\
will reach you the below assets \\
- Quality Editorial service \\
- Swift Peer Review \\
- Reprints availability \\
- E-prints Service \\
- Manuscript Podcast for convenient understanding \\
- Global attainment for your research \\
- Manuscript accessibility in different formats \\
( Pdf, E-pub, Full Text, Audio) \\
- Unceasing customer service \\
Track the below URL for one-step submission \\
https://juniperpublishers.com/online-submission.php \\
\hline
\end{tabular}

